\title{
A Study on the Burnt Offering
}

\author{
Saya Lee \\ Dept. General Education, Namseoul Univ., Cheonan, Korea \\ isaiah37@naver.com
}

\begin{abstract}
From the patriarchal time of the Old Testament to the destruction of the second temple (A.D. 70), the sacrifices were located at the center of ancient Israeli religion. The practice of the sacrifice varied in many ways in form and meaning. The sacrifice was the focal point of ancient Israel as a worshiping community. However, in the Old Testament, sacrifices show a double side like both sides of a coin. Moses founded the sacrificial system of Israel, and the Torah he preached to the Israelites tells us about the sacrifices in the tabernacle and the daily life outside the tabernacle. Nevertheless, the prophets of the Bible said that God hated sacrifices. They even viewed the sacrifice as sins against God. It tells us that even in the Old Testament times, right sacrifices were not practiced. The purpose of this study is to find the right meaning of worship to be performed in our time by examining the burnt offering, most representative of the various sacrifices presented in the Old Testament. In particular, by looking at the burnt offering that appears in the Old Testament, the author want to find the right worship service for our time. To this purpose, the author would like to examine the rules and meanings of the burnt offerings in the Old Testament, and how this sacrifice was applied in biblical history from the canonical-critical perspective.
\end{abstract}

Key Words: Burnt offering, Worship community, Leviticus, Tent of meeting, Pigeon, Cattle, Sheep, Goat

\section{Introduction}

Israel, as the Old Testament says, was a community of worship. Exodus, the most important event in the Old Testament, was not simply a political event that means Israel's liberation from slavery. It meant returning to the community of worshiping God [1]. In Israeli history after the Exodus, worship served as a keyword in the relationship between Israel and God. Nevertheless the prophets often proclaimed not to worship God. Why was that for? This makes us think a lot. Such a proclamation by the prophets was not really a statement not to offer sacrifices, nor a statement not to deny the importance of worship. Rather, it means that we should offer the right sacrifices God is pleased with.

Judaism and Christianity both are the religions of worship. In particular, it is no exaggeration to say that Christianity today is in the flood of worship. However, today's Christianity needs to be examined whether true worship is being conducted. Today, it is impossible to carry out burnt offerings as prescribed in the Old Testament, but it is necessary to keep the fundamental spirit of burnt offerings.

Judaism and Christianity both are the religions of worship. In particular, it is no exaggeration to say that Christianity today is in the flood of worship. However, today's

Article history:

Received (September 25, 2020), Review Result (October 28, 2020), Accepted (December 16, 2020)

JARR

Copyright (C) 2021 Global Vision Press (GV Press) 
Christianity needs to be examined whether true worship is being conducted. Today, it is impossible to carry out burnt offerings as prescribed in the Old Testament, but it is necessary to keep the fundamental spirit of burnt offering.

Just as it is very difficult to see historically how major feasts such as the Sabbath and Jubilee were actually practiced, it is also difficult to examine how the burnt offering were actually practiced in Israel's history. However, we can examine the meaning of burnt offering and the worship community through the events that appear in the canon. Finding and applying the true meaning of burnt offering is equally important in those days and today.

\section{Regulations in Leviticus}

\subsection{Leviticus and the tent of meeting}

Leviticus is a book for ancestral rites in the Old Testament. The book best illustrates the religious characteristics of Israel as a community of worship. Leviticus records how Israel as a community of worship should live, and various sacrifices and daily rules that God's people need to maintain a good relationship with God. It contains religious ordinances and regulations for feasts and sacrifices of the Old Testament including burnt offering, meal offering, peace offering, sin offering, compensation offering, and feasts and festivals such as Passover, Feast of Weeks, Feast of Booths, Sabbath and Jubilee.

There is a common misconception that Leviticus is a ritual provision for the Levites, who were mainly members of the priests, but in fact Leviticus deals in detail with the specific religious life of the entire people of Israel, not the words recorded for a particular group of priests. Therefore, the regulations for the people (Leviticus 1:1-6:7) came before the regulations for the priests (Leviticus 6:8-7:38). According to Leviticus I, God called Moses at the Tent of Meeting and delivered the laws for worship to the people of Israel through Moses. And the people of Israel met together in the tent of meeting to worship God. The Tent of Meeting was a place of worship and revelation [2].

The burnt offering mentioned here is the most representative of the various ancestral rites of the Old Testament; "Yahweh called to Moses, and spoke to him out of the Tent of Meeting, saying, 'Speak to the children of Israel, and tell them, when anyone of you offers an offering to Yahweh, you shall offer your offering of the cattle, from the herd and from the flock. If his offering is a burnt offering from the herd, he shall offer a male without blemish. He shall offer it at the door of the Tent of Meeting, that he may be accepted before Yahweh. He shall lay his hand on the head of the burnt offering, and it shall be accepted for him to make atonement for him"” (Leviticus 1:1-4).

The Hebrew word olah, which is a burnt offering, is derived from the verb alah, which means 'ascend', and expresses the image of fire, smoke, and fragrance rising high to God [3]. In the case of offering various sacrifices together, the burnt offering was performed first, while other sacrifices were later performed. The characteristic of this burnt offering was that it burned everything except the dirty parts(skin) that would be dumped outside and dedicated to God. The people including the priests could not eat at all. This kind of ritual was already widespread in the ancient Near East. There were two kinds of burnt offerings. One was performed by the priests, at the time of the Exodus the people of Israel were to offer a lamb through the priest every morning and evening at the tabernacle of the desert (Exodus 29:3841). The other was performed by the people, which was allowed to offer burnt offerings when an individual made atonement for his wrongs and wished for God's grace (Leviticus 1:2)

At the center of the ritual event was the burnt altar. This burnt altar must be "holy" after it 
was installed so that the daily sacrifice could be offered [4]. The burnt offering was carried out in cooperation with the priest and the people. When the man who brought the offering laid the hands on the head of the animal, grabbed the offering, skinned it, the priest placed the offering on the altar and burned it to God. He who offers sacrifices expressed his intention to give part(s) or all of himself with the beast to God by touching his hand on the head of the beast (Leviticus 1:4). By doing so, the giver was equated with the beast. That is, the death of a sacrifice is the death of a man, and the sacrifice to God meant giving himself [5]. The priest took the blood and sprinkled it around the altar. The sprinkling of blood had a symbolic meaning of returning to God the life of the beast as a sacrifice. It was understood that God had received the offering, which smelled fragrant when burned (Leviticus 1:9). The sin of men evokes the wrath of God and the wrath of God leads to judgment. But the people of Israel were able to soften the wrath of God by doing burnt offerings and avoid judgment. Because God has soothed his wrath by smelling the smoke of the burnt offering [6]. As such, the theory of "anthropomorphism," in which God is portrayed as a man with a nose like a human being, is often found in the regulations of the rite.

The priest had to keep an eye on the fire of the burnt altar: 'This is the law of the burnt offering: the burnt offering shall be on the hearth on the altar all night until the morning; and the fire of the altar shall be kept burning on it' (Leviticus 6:9). That the fire on the altar should not go out suggested that God was always there. For this purpose, even the oil from the peace offerings was used for the burnt offering. It is no longer required to offer burnt offerings every day because in the New Testament, Jesus' crucifixion is understood as a fullfledged sacrifice for human sin.

\subsection{Offerings}

The offerings used in the burnt offering were mainly male cows, sheep, and goats without blemish. Flawless offering means integrity, and male means the best. This is because in ancient society, males were given superior values than females. We can also think about the practical reasons that females need to feed and breed [7]. However, it was not easy to give a ram or a goat, which was equipped with seed livestock. Those who offer cattle, sheep and goats as males were comparatively economically affordable. The offerings made by the poor were birds. In the case of birds as a burnt offering, the main offering used was pigeon. The ancient Israelis raised pigeons at home: 'There was a great famine in Samaria: and, behold, they besieged it, until a donkey's head was sold for eighty pieces of silver, and the fourth part of a kab of dove's dung for five pieces of silver' (2 kings 6:25). Unlike cattle, sheep and goats, when a bird is offered, it was done by the priest without the participation of the people. It was probably because the bird was so small and it was impossible to distinguish between male and female [8]. After Jesus' birth, Joseph and Mary went up to Jerusalem to perform the mother's purification ceremony (Leviticus 12:1-8) and to give their firstborn son to God (Exodus 13:12,14-15). Their sacrifice as pigeons indicates that the family was poor: 'When the days of their purification according to the law of Moses were fulfilled, they brought him up to Jerusalem, to present him to the Lord (as it is written in the law of the Lord, Every male who opens the womb shall be called holy to the Lord"), and to offer a sacrifice according to that which is said in the law of the Lord, A pair of turtledoves, or two young pigeons'(Luke 2:2224).

What's interesting is that when a bird is sacrificed as a burnt offering, it should be burned on the altar in a state of "tearing its body from its wings, but not being torn". Why did the law tell the giver to tear up a small offering? The reason was to make the bird look bigger because 
it was too small for the cattle or sheep/goats that other people were offering. The worshiper's heart to offer God something even bigger and better, even though he was poor, appeared in the act of tearing the bird's body. The dove, which was offered in the spirit of offering the best to God, could never be said to be a small offering compared to cows, sheep, and goats offered by others. Jesus set a woman as an example to his disciples. Jesus praised the poor widow for giving two mites, probably because he read the heart of a woman who wanted to dedicate the best to God: 'Most assuredly I tell you, this poor widow gave more than all those who are giving into the treasury, for they all gave out of their abundance, but she, out of her poverty, gave all that she had to live on' (Mark 12:41-44). Jesus directed the disciples' eyes to the widow from the rich.

\section{Cases in the testaments}

\subsection{Abel's firstborn}

Cain and Abel were the first to offer sacrifices to the Lord. God received Abel's offering, but he refused Cain's offering. Although Cain was older and Abel was younger, Genesis introduces Abel first. This reversed order reappears in the event of sacrifice: 'Abel also brought some of the firstborn of his flock and of the fat of it. Yahweh respected Abel and his offering, but he didn't respect Cain and his offering. Cain was very angry, and the expression on his face fell' (Genesis 4:4-5). The important thing here is that God took only Abel's sacrifice. Why? The answer is simple. For God was pleased with Abel. He respected 'Abel and his offering'. The first sacrifice-story of the Old Testament shows that people are prioritized over offerings. It is clear that God did not accept Cain and his offering because the life of Cain did not make him happy, rather than that the offering itself was flawed (1 John 3:12; Hebrews 11:4). For Abel had lived a righteous life, so God received Abel himself as a sacrifice. And Abel's firstborn lamb and its oil developed into the best offering the Israelites could offer to God in the future (Exodus 13:2; Deuteronomy 15:19).

\subsection{Noah \& David's relieving god's wrath}

The word burnt offering in the Old Testament first appeared immediately after the flood of Noah's time. The first thing Noah did when he came out of the Ark was to take sacrifices among all the clean beasts and birds. He did a burnt offering to God with them (Genesis 8:20). Noah's burnt offering has two meanings. One was a gratitude for the grace of God saving from the flood judgment, and the other was asking God for grace for the future of his new life. After the burnt offering, God gave new grace to the world of creation. It was that God does not curse the earth because of men again (Genesis 8:21). In response to the burnt offering of a man Noah, God promised to be faithful to the whole world forever. Generally, sacrifices in the ancient Near East were done for two purposes. It was first, to provide food to God, and second to appease God [9]. The burnt offering in the Old Testament also had the meaning of relieving God's wrath. Not only Noah's burnt offering, but David's burnt offering also had the same meaning. David relieved the wrath of God, which was caused by the census, by offering burnt offering: 'David built there an altar to Yahweh, and offered burnt offerings and peaceofferings. So Yahweh was entreated for the land, and the plague was stayed from Israel' (2 Samuel 24:25).

\subsection{Abraham's Obeying}


In Genesis 22, The event that Abraham's attempted to offer his son Isaac as burnt offering was the most dramatic worshipping scene in the Old Testament. Here Abraham took just the trees, the fire, and the sword to be used in the burnt offering (Genesis 22:6). Isaac said to Abraham, 'Where is the Lamb for burnt offerings?' (Genesis 22:7). At the end of the story, Abraham took the ram and offered burnt offering on behalf of his son (Genesis 22:13). The story illustrates the typical burnt offering. God said to Abraham, "Now take your son, your only son, whom you love, even Isaac, and go into the land of Moriah. Offer him there for a burnt offering on one of the mountains which I will tell you of' (Genesis 22:2). Isaac, who appeared in the story, appears to be a young man over the age of twenty because it was long enough for Isaac to appear on the mountain carrying a tree for the burnt offering. If so, father Abraham was about 120 years old. Abraham, an old man, took the trees for the burnt offering and gave it to his son Isaac, and he took the fire and the sword and went to the place God had told him. And there he bound his son Isaac as a sacrifice (Genesis 22:9-10).

In this process, if the father and the son competed with each other, Abraham, who had already become an old man, would have lost to his young son Isaac. Abraham's burnt offering could have been possible because Isaac was voluntarily bound for Abraham. Therefore, the earliest targum, The Fragmentary Targum, suggested that Isaac was willing to sacrifice himself: "Abraham stretched out his hand and picked up a sword to kill his son Isaac. Isaac answered to his father Abraham, 'Tie my hands firmly so that I will not resist when I am in pain, and I will not interfere with you, nor will you defile your sacrifices, so that you will not fall into the depths of destruction in the coming world.' Abraham turned his eyes to Isaac's eyes, but Isaac's eyes turned to an angel of heaven. Isaac saw the angels, but Abraham did not see them. Then the angels of heaven came out and said to one another, 'Let us go and see the two faithful men of the world. One is a slaughter and the other is slaughtered. The one who kills does not hesitate, and the one who is slain puts forth his neck"' [10][11].

\subsection{Saul's Deterioration}

The kingdom of Israel began with Saul. He was a modest man: 'Am I not a Benjamite, of the smallest of the tribes of Israel? and my family the last of all the families of the families of the Benjamin?' But his humility did not last long. Not long after he ascended the throne, Saul lost his beautiful character and made some mistakes. One of them was the voluntary execution of the burnt offering without waiting for Samuel the priest while preparing for the war against the Philistines: 'He stayed seven days, according to the set time that Samuel had appointed: but Samuel didn't come to Gilgal; and the people were scattered from him. Saul said, Bring here the burnt offering to me, and the peace-offerings. He offered the burnt offering' (1 Samuel 13:8-9). He offered sacrifices he should not have dared to offer to concentrate the attention of the people. Because of this incident, King Saul was eventually handed over from the throne.

\subsection{Solomon's a thousand sacrifices}

In 1 Kings 3, one of the most impressive and beautiful stories of Solomon's record comes up. Solomon visited the great high place in Gibeon to execute the burnt offering to the LORD. Deuteronomistic Historians were very negative about high place because it was the place of mixed religions. But Solomon did 'a thousand burnt offerings' at the high place in Gibeon. There, Solomon obtained it by begging for a 'listening heart(lev-shomea)' so that he could judge his people well. 
But Solomon lost his heart because of his 'thousand wives' and idols they had brought with them. What was Solomon's heart that made the women turn away? It was a "listening heart" obtained through 'thousand burnt offering'. And when he lost the heart that God had given him, the heart of God had left him, and the hearts of the people had left him [12].

\subsection{Authors of the new testament}

In the New Testament, the term burnt offering only appears twice. However, the meaning of burnt offering frequently appears in relation to the ministry of Jesus Christ. We were given the redemption by the precious blood of Christ, the spotless and spotless lamb(1 Peter 1:1819). Christ gave himself to God as a fragrant offering and sacrifice for us(Ephesians 5:2) and, on behalf of the burnt offering, performed eternal sacrifice and sat at the right hand of God(Hebrews 10:11-12). Thus, the authors of the New Testament interpreted the burnt offering of the Old Testament Christologically. According to them, repeated sacrifices, like the burnt offering of the Old Testament, are no longer necessary because the son of God, a more noble offering in place of animal offerings, gave his body to atone for it [13].

\section{Conclusion}

The burnt offering is the most important and representative sacrifice in the Old Testament and conveys some important ideas to modern Christianity and church. First, the worshiper is more important than the offering. The rich devote cattle, the middle class devote sheep or goats, while the poor devote birds. The value of birds is never lighter than cattle, sheep, or goats. The important thing is the heart of the giver. Rather than offering with a stingy heart, it is more important to give with a heart of volunteering and gratitude. Second, the burnt offering must be intact and complete. Burning does not mean that only part of it is dedicated, but all of it is devoted. Abraham's sacrifice of Isaac means that he has completely dedicated his future to God. Third, all services shall be joined together by the priest and the congregation. The burnt offering was not for the priest alone. It is significant that the person who brought the offering and the priest shared the work. The service to God should not be all the burdens of one person, but the worship of "together." Rather than today's services centered on pastors, the participation of laymen in many areas needs to be more actively accepted.

In addition to the Leviticus, the Old Testament tells in detail what sacrifices Israel, as a community of worship, should offer before God. But not all sacrifices are received by God. The prophets of the Old Testament said in unison: 'Do not offer sacrifices' (Amos 5:20-25; Hosea 8:11-13; 10:5-8; Isaiah 1:10-15; 66:3 etc.) [14].

The burnt offering of the Old Testament corresponds to the daily services of today. Now we must expand the category of worship we offer to God. Worship does not end in the chapel. To worship is to continue the spirit of sacrifice in the world. Every place in our lives is the place of burnt offering. The Old Testament emphasizes the nature of the sacrifice that God is really pleased with in many places. A sincere offering is important even if it is less than many offerings, and it is more important to live a straight and upright life than a ritual biased toward formality (Malachi 1:8-10; Isaiah 1:11-17; Micah 6:6-8; Psalm 51:16-19, etc.). Man is God's holy temple. This is why one should be wary of and stay away from flaws and pollution in life. Paul's affirmation will be that the life of the holy Christian is a ritual that God rejoices in.

\section{References}


[1] S. Lee, "Spirit and Spirituality revealed on moses as the leader of multicultural religious community," Culture \& Theology, Seoul: Korean Society of Culture and Theology, vol.4, pp.111-136, (2009)

[2] D. Kim, "Holiness: Encountering with holy god in the sanctuary," Yongin: Kingdom Books, pp.63, (2011)

[3] L. Koehler and W. Baumgartner, "olh," The Hebrew and Aramic Lexicon of the Old Testament, Leiden: Brill, vol.1, pp.828-830, (2001)

[4] R, Rolf, "Theologie des alten testaments: ein kanonischer entwurf," trans. by Kyung-Taek Ha, Seoul: CLC, pp.128, (2020)

[5] G. A. F. Knight, "Leviticus,” Louisville: John Knox Press, pp.14, (1981)

[6] D. Kim, "Holiness: Encountering with holy god in the sanctuary," Yongin: Kingdom Books, pp.77, (2011)

[7] J. Milgrom, "Leviticus 1-16: A new translation with introduction," New York: Doubleday, pp.147, (1991)

[8] D. Kim, "Holiness: Encountering with holy god in the sanctuary," Yongin: Kingdom Books, pp.75, (2011)

[9] M. Selman, "Sacrifice in the ancient near east," Sacrifice in the Bible, eds. Roger T. Beckwith/Martin J. Selman, Grand Rapids: Baker House Books, pp.88-104, (1995)

[10] E. Kessler, "Bound by the bible: Jews, Christians and the Sacrifice of Isaac," Cambridge University Press, pp.123, (2004)

[11] Y. Lee, "Biblical exegesis and the ethics of hermeneutics," KJOTS, vol.30, pp.10-30, (2008)

[12] S. Lee, "Listening heart(Lev shomea) of solomon and wisdom of proverbs," International Journal of Recent Advances in Multidisciplinary Research, vol.5, pp.4051-4053, (2018)

[13] D. Kim, "Holiness: Encountering with holy god in the sanctuary," Yongin: Kingdom Books, pp.80, (2011)

[14] S. Lee, "The worship-critique and social ethics of eighth-century prophets in micah 6:6-8," University and Mission, Seoul: The Korean Association for University Mission Studies, vol.35, pp.103-130, (2017) 
This page is empty by intention. 